\title{
A Contextual Approach to Unconstitutional Constitutional Amendments: Judicial Power and the Basic Structure Doctrine in Malaysia
}

\author{
Jaclyn L. NEO* \\ Faculty of Law, National University of Singapore \\ jaclyn.neo@nus.edu.sg
}

\begin{abstract}
This article takes a contextual approach to analyzing judicial engagement with the doctrine of unconstitutional constitutional amendments. It argues that in assessing judicial reception of the basic structure doctrine, and the content of the constitutional identity that such a doctrine seeks to preserve, a normative universalist or even functionalist approach is not sufficient. Instead, such a doctrine should be justified and understood contextually. It is necessary to contextualize constitutional identity in order to give it a robust character, rather than assuming a set of characteristics most often associated with liberal democratic constitutionalism and without understanding the political, social, and economic conditions in which the constitution operates. This article thus uses the example of Malaysia and how the courts have engaged with the basic structure doctrine to show how a contextual approach could have greater explanatory effect, including on why certain issues are more strongly contested in some countries than in others.
\end{abstract}

Modern constitutions embody foundational agreements on how to organize power and establish a political order. A typical constitution today sets out the form of government, the limits of government, and oftentimes, the goals for the exercise of governmental power. ${ }^{\mathrm{I}}$ It is theoretically the source of all legal governmental powers and authority. However, does a constitution have core characteristics that are so fundamental to its identity that any amendment to these should be strongly resisted or even declared 'unconstitutional'? In other words, are there certain structural or

* Associate Professor, Faculty of Law, National University of Singapore; Director, Centre for Asian Legal Studies. I would like to thank my two anonymous reviewers for this Journal for their reviews and for encouraging me to develop some parts of the article further. I would also like to thank Louis Lai and Philip Teh for their research assistance. This article was developed from a draft prepared for a conference organized by the German-Southeast Asian Center of Excellence for Public Policy and Good Governance (CPG) at Thammasat University on 'The Basic Structure in Asian Constitutional Orders'. I would also like to thank an anonymous reviewer for the CPG for his/her helpful comments.

I. Stephen Holmes, 'Constitutions and Constitutionalism', in Michel Rosenfeld \& András Sajó (eds), The Oxford Handbook of Comparative Constitutional Law (Oxford University Press 201 2 ) I89. 
substantive features of the constitution that are so basic to it that they simply cannot be removed or altered without completely destroying the constitution as we know it? This is a question that has occupied a significant part of constitutional debate, whether couched as a discussion of unconstitutional constitutional amendments or in the more specific variant known as the basic structure doctrine. ${ }^{2}$ This constitutional idea that there are substantive limits to amendment power is one of the most widely dispersed doctrines in recent times. Substantive, as opposed to procedural, limits to constitutional amendment powers could be imposed explicitly, such as where the constitution itself designates certain provisions as being unamendable. Germany's eternity clauses are one such example; the principles set out in these clauses are declared to be immutable and mark out a 'normative core that defined the constitutional identity of the polity'. ${ }^{3}$ Preuss points out therefore that 'these principles could not be altered without destroying this very identity' ${ }^{4}$

Besides such textual inclusions, another interesting development has been the judicial construction of the basic features/basic structure doctrine, where certain core features are identified as basic to the constitution and therefore unamendable. These features are judicially derived from the constitutional text and structure. They supposedly reflect dominant political theory and/or are apparently supported by constitutional history. This basic features doctrine was famously articulated by the Indian Supreme Court ${ }^{5}$ in the case of Kesavananda Bharati $v$ The State of Kerala, ${ }^{6}$ where the majority held that the Parliament of India could not amend the Constitution of India in a way that destroys its basic structure or features. As Chief Justice Sikri put it, the amending power under the Constitution of India 'is wide enough to permit amendment of each and every article of the Constitution by way of addition, variation or repeal so long as its basic elements are not abrogated or denuded of their identity."7

2. For a discussion of this question see eg Carl Schmitt, Constitutional Theory (Jeffrey Seitzer tr, Duke University Press 2008); Frederick Schauer, 'Amending the Presuppositions of a Constitution', in Sanford Levinson (ed), Responding to Imperfection: The Theory and Practice of Constitutional Amendment (Princeton University Press I995); Gary Jacobsohn, Constitutional Identity (Harvard University Press 2010); Richard Albert, 'Constitutional Amendment and Dismemberment' (20I8) 43 Yale Journal of International Law I; Yaniv Roznai, Unconstitutional Constitutional Amendments: The Limits of Amendment Powers (Oxford University Press 2017). For a more recent, expanded development of the concept, see David Landau, Rosalind Dixon \& Yaniv Roznai, 'From an Unconstitutional Constitutional Amendment to an Unconstitutional Constitution? Lessons from Honduras' (2019) 8 Global Constitutionalism 40.

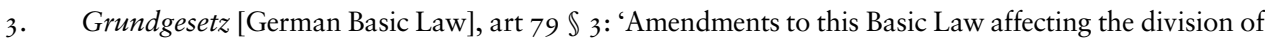
the Federation into Länder, their participation on principle in the legislative process, or the principles laid down in Articles I [human dignity] and 20 [the rule of law, republicanism, democracy, social state, and federalism] shall be inadmissible.' These clauses cannot be changed through constitutionally-prescribed means. For an examination of the implications of these clauses, see Ulrich K Preuss, 'The Implications of "Eternity Clauses": The German Experience' (2OII) 44 Israel Law Review 429.

4. ibid $44 \mathrm{I}$.

5. Note however the influence of German constitutional doctrine on India's basic structure doctrine: Sudhir Krishnaswamy, Democracy and Constitutionalism in India: A Study of the Basic Structure Doctrine (Oxford University Press 2009) xxvi-xxvii.

6. [I973] AIR (SC) I46I.

7. ibid para 6I9 (Sikri CJ) (emphasis added). 
This basic structure doctrine has now entered the constitutional lexicon of a whole range of countries, especially in Asia. ${ }^{8}$

However, one has to look no further than Justice Ray's dissenting opinion in Kesavananda to identify two persistent objections to this doctrine. The first objection concerns the identification of these features. As Justice Ray put it, '[w] hen the constitution does not make any distinction between essential and non-essential features it is incomprehensible as to how such a distinction can be made'. 'According to him, finding out what are essential or non-essential features 'is an exercise in imponderables'. ${ }^{\text {ro }}$ The second objection goes to the issue of institutional legitimacy - should the judiciary be in a position to draw distinctions between basic and non-basic features? As the basic features doctrine is a judicial doctrine, its applicability must implicate questions of the judicial role within the constitutional framework and the constitutional theory animating that particular constitutional system. The doctrine can thus be distinguished from situations where there is an explicit textual basis for identifying unconstitutional constitutional amendments. It is a matter of constitutional interpretation.

The allure of the basic structure doctrine is understandable from a constitutionalist perspective. The power to amend is part of the constitutional design and is seen as necessary to 'preserve the flexibility and sustainability of the constitutional order'. ${ }^{\text {I }}$ However, if there are no limits to the amendment power, it could be used to destroy what are seen as the core values of the constitution. Landau argues that some uses of the mechanism of constitutional change erode the democratic order and are a form of 'abusive constitutionalism'. ${ }^{12}$ This approach takes liberal democratic constitutionalism as the measure to characterize an abuse of constitutional amendment powers. However, objections to unlimited constitutional amendment powers may go beyond putative commitments to liberal democratic constitutionalism. Instead, a constitutional amendment may be objectionable, or at least worthy of robust scrutiny, when it radically changes the nature of the constitution.

Albert proposes characterizing some constitutional amendments not as 'amendments' but as 'constitutional dismemberment', which he defines as 'self-conscious efforts to repudiate the essential characteristics of the constitution and to destroy its

8. In South Asia, the basic structure doctrine's influence has been discussed in eg Osama Siddique, 'Across the Border: A New Avatar for India's Basic Structure Doctrine' (2010) 6I5 Seminar: A Monthly Symposium on 60 Years of the Indian Constitution (I950-2010) 52; Ridwanul Hoque, 'Constitutionalism and the Judiciary in Bangladesh', in Sunil Khilnani, Vikram Raghavan \& Arun

$\mathrm{K}$ Thiruvengadam (eds), Comparative Constitutionalism in Asia (Oxford University Press 20I3) 303. For an exposition of the basic structure doctrine in India, see Madhav Khosla, 'Constitutional Amendment', in Sujit Choudhry, Madhav Khosla \& Pratap Bhanu Mehta (eds), The Oxford Handbook of the Indian Constitution (Oxford University Press 20I6) 233. In Southeast Asia, besides Malaysia, the basic structure doctrine has also been considered by the courts in Singapore: see eg Jaclyn L Neo, 'Towards a "Thin" Basic Structure Doctrine in Singapore' (I-CONnect Column) (I-CONnect, I7 Jan 20I8) <http://www.iconnectblog.com/20I 8/I/towards-athin-basic-structure-doctrine-in-singapore-i-connect-column/> accessed 29 Apr 2020; Chan Sek Keong, 'Equal Justice under the Constitution and Section 377A of the Penal Code: The Roads Not Taken' (2019) 3 I Singapore Academy of Law Journal 773.

9. ibid 949 (Ray J).

Io. ibid.

II. Preuss (n 3) 430 .

I2. See generally David Landau, 'Abusive Constitutionalism' (2013) 47 UC Davis Law Review I89. 
foundations'. ${ }^{\text {I3 }} \mathrm{He}$ argues that while a constitutional amendment is 'an adjustment made to better achieve the purpose of the existing constitution', a constitutional dismemberment is 'incompatible with the existing framework of the constitution because it seeks to achieve a conflicting purpose', 'seeks deliberately to disassemble one or more of the constitution's constituent parts', and 'alters the identity, fundamental values or the architecture of the constitution'. ${ }^{44}$ In other words, such changes could be said to 'unmake the constitution'. ${ }^{15}$ Debates about amendment powers and the necessity or desirability of substantive limits on amendment powers are essentially about the polity's constitutional identity. It is about what institutional and sociopolitical values - whether reflected in institutional structure or otherwise - should be preserved, at least against short-term interests.

This identity-preserving argument for a doctrine of unconstitutional constitutional amendments or its specific variant, the basic structure doctrine, is persuasive to some extent, though it does not fully address the objections of imponderability and legitimacy. Nonetheless, in practice, the objection on the basis of imponderability has been less strong than one might assume. Even where judges do not adopt the basic structure doctrine, they appear to have little difficulty identifying what the basic or core features of the constitution are. Thus, even in a country like Singapore where judges continue to resist the full force of the Kesavananda doctrine, they have been able to tentatively identify what features (eg separation of powers, rule of law, ${ }^{16}$ or even the right to vote $^{\mathrm{I7}}$ ) could fall within the basic structure of the constitution.

That judges are able to identify such features, even when they disagree with the doctrine, may suggest that there are foundational ideas that most constitutional lawyers could agree with. It also says something about the context in which constitutions operate. These constitutions operate within particular constitutional traditions and are sustained by a constitutional culture, however nascent that may be. To say that the separation of powers is a basic feature is also to say that it is part of an established constitutional tradition and is accepted as a necessary aspect of the constitutional structure in that particular country. Constitutional identity must be seen as contextual, rather than abstract. A contextual understanding is therefore necessary to comprehend whether and how judges may accept the doctrine of unconstitutional constitutional amendment, or more specifically, the basic structure doctrine.

Thus, in this article, I argue that judicial treatment of the doctrine must be contextually analyzed. Indeed, such judicial treatment often reflects the judiciary's view about, and its response to, its relationship with the political branches. A contextualized institutional analysis is a crucial aspect of the study of the judicial doctrine of unconstitutional constitutional amendment. To illustrate this argument, I adopt a contextual approach in analyzing resistance to constitutional amendments through

I3. Richard Albert, 'Constitutional Amendment and Dismemberment' (20I8) 43 Yale Journal of International Law I, I-2.

I4. ibid 4 .

I 5. ibid.

I6. Ravi s/o Madasamy v Attorney-General [20I7] SGHC I63, [20I7] 5 SLR 489.

I7. Yong Vui Kong $v$ Public Prosecutor [20I 5] SGCA II, [20I 5] 2 SLR I I 29. 
an examination of the evolution of the Malaysian judiciary's engagement with the basic structure doctrine. I argue that this engagement should be seen in the context of the judiciary's relationship with the political branches. Indeed, I suggest that when there was a relationship of mutual respect between the judiciary and the political branches, the judiciary took the basic structure doctrine into consideration in various judgments but was reluctant to adopt the basic structure doctrine. In comparison, in the aftermath of a constitutional crisis in I 988 that seriously undermined judicial independence, for a time, the basic structure doctrine did not feature in judicial reasoning. During this period, the judiciary largely avoided confrontations with the political branches. However, in more recent times, particularly since 20I0, the judiciary has started to assert its judicial authority, and one of the ways in which it has done so is by engaging with and embracing (albeit tentatively at first) the basic structure doctrine. Accordingly, I argue that at the heart of the debate about the applicability of the basic structure doctrine in Malaysia is a contestation about a core aspect of Malaysia's constitutional identity: whether it adheres to parliamentary supremacy where the judiciary is subordinate to Parliament (and even the executive), or constitutional supremacy where the judiciary is co-equal to the other branches of government.

\section{A CONTEXTUAL APPROACH TO UNCONSTITUTIONAL CONSTITUTIONAL AMENDMENTS}

The starting point of a contextual approach to constitutional law is 'that constitutional ideas can be understood only in the full institutional and doctrinal context within which they are placed'. ${ }^{18}$ Constitutional developments reflect the 'ideas, values, attitudes, and opinions people in a given polity hold with respect to law and the [c] onstitution'. ${ }^{19}$ Spigno observes that context is the 'central element for the understanding of legal phenomena'. ${ }^{20}$ Indeed, as Hirschl points out, constitutions do not originate or operate in a vacuum, and ' $[t]$ heir import cannot be meaningfully described or explained independent of the social, political, and economic forces, domestic and international, that shape a given constitutional system'. ${ }^{2 \text { I }}$ Accordingly, the constitutional domain should not be portrayed as 'predominantly legal' but as 'imbued in the social or political arena', lest one produces only 'thin, a-historical, overly doctrinal or formalistic accounts of the origins, nature and consequences of constitutional

I8. Mark Tushnet, Weak Courts, Strong Rights: Judicial Review and Social Welfare Rights in Comparative Constitutional Law (Princeton University Press 2008) 5.

I9. Wen-Chen Chang et al, Constitutionalism in Asia: Cases and Materials (Bloomsbury Publishing 20I4) 68.

20. Irene Spigno, 'Methodologies of Comparative Constitutional Law: Contextual Approach', in Rainer Grote, Frauke Lachenmann \& Rüdiger Wolfrum (eds), Max Planck Encyclopedia of Comparative Constitutional Law (Oxford University Press 2017) < https://oxcon.ouplaw.com/view/I0.I093/law$\mathrm{mpeccol} / \mathrm{law}-\mathrm{mpeccol}-\mathrm{e} 47$ ? rskey=tBzFgO\&result=I I 8 prd=MPECCOL $>$ accessed 29 Apr 2020.

2I. Ran Hirschl, 'From Comparative Constitutional Law to Comparative Constitutional Studies' (20I3) I I International Journal of Constitutional Law I, 2. 
law'. ${ }^{22}$ A contextual approach to law would be just as pertinent to the study of a single jurisdiction as to a comparative constitutional study. ${ }^{23}$

In assessing the suitability of the basic structure doctrine for a constitutional system and the constitutional identity that such a doctrine seeks to preserve, a normative universalist or even functionalist approach is not sufficient. Instead, as Stone points out, any justification for a doctrine of unconstitutional constitutional amendment has to be justified and understood contextually, and depends on the nature of a given constitutional order. ${ }^{24}$ It is necessary to contextualize constitutional identity in order to give it a robust character, rather than assuming a set of characteristics most often associated with liberal democratic constitutionalism and without understanding the political, social, and economic conditions in which the constitution operates. This is especially since constitutional identity, as Jacobsohn argues, is a far more fluid idea and 'may manifest itself differently in different settings'. ${ }^{25}$ Furthermore, a constitution acquires an identity through experience, emerging 'dialogically' and representing 'a mix of political aspirations and commitments that are expressive of a nation's past, as well as the determination of those within the society who seek in some ways to transcend the past'. ${ }^{26}$ A contextual approach will also have greater explanatory effect as to why certain issues are more strongly contested in some countries than in others. It will highlight why not all foundational characteristics are deemed foundational and contested at all times everywhere. Engaging in contextual analysis entails a degree of constitutional ethnography, which focuses our mind on 'the logics of particular contexts as a way of illuminating complex interrelationships among political, legal, historical, social, economic, and cultural elements. ${ }^{27}$ As a doctrine of unconstitutional constitutional amendment is grounded in a conception of constituent power, one may even suggest that constituent power is not only contested, ${ }^{28}$ but also contextual. Thus, to understand why certain features of the constitution become especially embroiled in disputes where the doctrine of unconstitutional constitutional amendments is deployed, one has to look at the underlying contexts, which would also include the judiciary's evolving relationship with the political branches.

\section{TIERED AMENDMENT PROCEDURES UNDER THE FEDERAL CONSTITUTION}

Contextualization requires us to go beyond the text of the constitution, including the provisions on constitutional amendments, to understand what features become hotly

\footnotetext{
22. ibid.

23. On the importance of context in comparative constitutional law, see generally Ran Hirschl, 'The Question of Case Selection in Comparative Constitutional Law' (2005) 53 American Journal of Comparative Law I25.

24. See Adrienne Stone, 'Unconstitutional Constitutional Amendments: Between Contradiction and Necessity' (2018) I 2 ICL Journal 357.

25. Gary Jeffrey Jacobsohn, Constitutional Identity (Harvard University Press 2010) 7.

26. ibid.

27. Kim Lane Scheppele, 'Constitutional Ethnography: An Introduction' (2004) 38 Law \& Society Review 389, 390.

28. For an exposition of constituent power, see generally Martin Loughlin, 'The Concept of Constituent Power' (2014) I3 European Journal of Political Theory 2 I 8.
} 
contested and why. In Malaysia, a tiered scheme of amendment procedures shows that issues concerning citizenship, language, prerogatives of the Malay rulers, as well as the autonomy of Sabah and Sarawak are given distinctive importance, with additional requirements for any amendment. The Federal Constitution of Malaysia (Federal Constitution) expressly declares itself to be 'the supreme law of the Federation' and further provides that 'any law passed after Merdeka Day which is inconsistent with this Constitution shall, to the extent of the inconsistency, be void. ${ }^{29}$ Like most constitutions today, the Federal Constitution also expressly provides for formal procedures for amendment, which allows for crucial flexibility. Its amendment procedure is rather complex, with four groups of provisions subject to different amendment requirements. First, the most prevalent mode of amendment is by a special two-thirds majority in both houses of Malaysia's bicameral federal Parliament, as set out in Article I 59 of the Federal Constitution. This is the general requirement for constitutional amendments, unless specifically excluded.

Secondly, the consent of the Conference of Rulers (Majlis Raja-Raja) is additionally required to amend a range of provisions touching upon citizenship, national language, reservations for Malays and natives of Sabah and Sarawak, as well as the sovereignty, prerogatives, and jurisdiction of the Malay rulers. ${ }^{30}$ The Conference of Rulers is comprised of the rulers of each state in Malaysia. ${ }^{3 \text { I }}$ Specifically, there are several provisions that require the consent of the Conference of Rulers to amend, namely Article Io(4) (limiting freedom of speech and expression); ${ }^{32}$ Article 152 (on the national language); Article 153 (on the reservations of quotas for Malays and natives of Sabah and Sarawak); Article I 8 I (on the sovereignty, prerogatives, powers and jurisdiction of the state Rulers); the provisions of Part III (on citizenship); Article 38 (on the Conference of Rulers); Article 63(4) (limiting parliamentary immunity over seditious speech and speech proscribed under Article Io(4)); Article 70 (on the precedence of the Rulers); Article 7I(I) (on the Federal guarantee of the rights of a Ruler of a State); Article 72(4) (limitation of legislative assembly immunity over seditious speech and speech proscribed under article IO(4)); Article I 52 (on the national language); and Article I 53 (on the reservation of quotas for Malays and natives of Sabah and Sarawak).

Thirdly, amendments affecting the constitutional position of the East Malaysian states of Sabah and Sarawak also require the consent of the heads of state of these states, where relevant. ${ }^{33}$ These instances include provisions on citizenship, the High Court in Sabah and Sarawak, state legislative powers, state executive powers, statefederal financial arrangements, religion in the state, language and special treatment of natives of the state, the allocation of members of the House of Representatives to these states, as well as entry into and residence in the states.

\footnotetext{
29. Federal Constitution of Malaysia, art 4(I).

30. ibid art $38(4)$, I $59(5)$.

3I. ibid art 38 , Fifth Schedule.

32. ibid art IO(4), which authorizes Parliament to pass laws prohibiting the questioning of any matter, right, status, position, privilege, sovereignty, or prerogative established or protected by the provisions of Part III (on citizenship), art I52, art I 53, or art I8I.

33. ibid art $16 \mathrm{IE}$.
} 
Fourthly, Article I 59(4) of the Federal Constitution expressly excludes the following provisions from the two-thirds majority requirement: (I) Part III of the Second Schedule (on registration of citizenship); (2) the Sixth Schedule (forms of oaths and affirmations); (3) the Seventh Schedule (mode of election of senators); (4) Parliament's legislative powers other than powers in relation to the states under Articles 74 and 76; (5) admission of any state to the Federation other than in relation to Sabah and Sarawak; and (6) amendments consequential to an amendment under the exception clause. It has been suggested that the exclusion of these provisions from the two-thirds majority requirement means that only a simple majority is required to amend them. ${ }^{34}$ This is especially since Article I 59(I) states that 'the provisions of this Constitution may be amended by federal law', unless otherwise provided for. However, from a constitutional theory perspective, if parts of the Federal Constitution can be amended by simple majority, this blurs the distinction commonly drawn between ordinary and higher/constitutional law, which is the prescription of amendment procedures of different levels of difficulty. ${ }^{35} \mathrm{~A}$ constitutional or higher law should, conceptually speaking, be harder to amend than ordinary laws. This muddling of the boundaries between constitutional law and ordinary law is also reflected in the curious feature of the Federal Constitution under Article I 59(5), which requires amendments to laws passed under Article Io(4) to be subject to a two-thirds majority in both Houses of Parliament. Article Io(4) allows Parliament to pass laws restricting speech that questions 'any matter, right, status, position, privilege, sovereignty or prerogative' that is established or protected under the provisions on citizenship, national language, special privileges for the Malays and natives of Sabah and Sarawak, and the sovereignty, prerogatives, powers and jurisdiction of the state Rulers, in the interest of security or public order.

Clearly, a tiered amendment procedure scheme can have an important expressive purpose, as it could be seen as reflecting the most fundamental values in a polity. ${ }^{36}$ In addition, Dixon and Landau argue that tiered amendment procedures could have crucial democracy-defending functions and could be employed to 'protect against certain destabilizing forms of constitutional change.' ${ }^{37}$ However, this tiered scheme does not provide much insight into why judicial power has become so critically contested and has become the basis for the courts' embrace of the basic structure doctrine. Judicial power is not especially protected; any amendment to judicial power merely requires the standard two-thirds majority vote in Parliament. Yet, judicial power has become the subject of great contestation, implicating a whole host of constitutional values including fundamental liberties and the preservation of constitutionally-limited government. In the next section, I will examine judicial

\footnotetext{
34. Loh Kooi Choon v Government of Malaysia [1977] 2 MLJ I87 (Federal Court).

35. AV Dicey, Introduction to the Study of the Law of the Constitution (Liberty Fund 1982) 39-40, 78-8I.

36. See eg Richard Albert, 'The Expressive Function of Constitutional Amendment Rules' (2013) 59 McGill 225.

37. For an analysis of tiered constitutional amendment procedures, see Rosalind Dixon \& David Landau, 'Tiered Constitutional Design' (2018) 86 The George Washington Law Review 438.
} 
receptivity (or otherwise) to the basic structure doctrine and situate it within an evolving relationship between the judiciary and the political branches.

\section{FROM RESISTANCE TO RECEPTIVITY: THE CONTEXTUAL EVOLUTION OF A DOCTRINE}

As mentioned, a contextual approach could assist us in better understanding why judges in some countries have adopted or resisted the basic structure doctrine at any point in time, as well as why a particular feature has become the subject of contestation. This is definitely the case in Malaysia, where the slow reception of the basic structure doctrine could be understood in the context of the judiciary's evolving relationship with the political branches. While the cases involving the application of the doctrine inevitably implicated fundamental rights, the real contestation was not only about the scope of rights, ${ }^{38}$ but also about the role of the judiciary vis-à-vis the political branches in Malaysia's constitutional democracy. ${ }^{39}$ The cases, which show an evolution from resistance to indifference to receptivity, demonstrate a correlation between the degree of acceptance of the basic structure doctrine and judicial self-understanding of its role within the constitutional order. Contextualization also allows us to understand why the doctrine has become particularly important in the tussle between the courts and the political branches over judicial power in Malaysia. It shows that while tentative conceptualization of a basic structure in Malaysia initially comprised features that could be regarded as universally foundational to a constitutionalist federal state, there was subsequent emphasis on judicial power because the judiciary was asserting itself within a particular constitutional context.

For our purposes, we can identify three important periods in this relationship between the judiciary and the political branches, and these coincide with three shifts in judicial philosophy. The first period is characterized by judicial resistance and ambivalence to the basic structure doctrine. This resistance must be understood in the context of a relationship of mutual respect between the judiciary and the political branches. As Tun Mohamed Suffian, a former Lord President of Malaysia, observed in 1987 , the first three Prime Ministers who served from I957 to I98 I were lawyers who understood the importance of judicial independence. There was an amicable relationship of respect among the different branches of government during this initial period of Malaysian independence. ${ }^{40}$ It is thus notable that during the period between

\footnotetext{
38. This contrasts with Tew's argument that the contestation was primarily about the scope of rights: Yvonne Tew, 'On the Uneven Journey to Constitutional Redemption: The Malaysian Judiciary and Constitutional Politics' (2016) 25 Washington International Law Journal 673, 692-694.

39. See generally Richard SK Foo, 'Malaysia - Death of a Separate Constitutional Judicial Power' [20Io] Singapore Journal of Legal Studies 227; Po Jen Yap, Courts and Democracies in Asia (Cambridge University Press 2017) ch 3.

40. HP Lee, Constitutional Conflicts in Contemporary Malaysia (2nd edn, Oxford University Press 20I7) 22.
} 
I 957 and the I980s, the judiciary issued judgments that deferred ${ }^{4 \mathrm{I}}$ to the government on many political issues, including national security issues. ${ }^{42}$ The early cases of Lob Kooi Choon $v$ Government of Malaysia ${ }^{43}$ and Phang Chin Hock $v$ Public Prosecutor $^{44}$ (discussed below) were decided during this time, when there was great confidence in the independence of the judiciary.

The second period is marked by the 1988 constitutional crisis, which pitted the judiciary against the executive branch, and its aftermath. The constitutional crisis seriously undermined judicial independence in Malaysia. It marked a significant shift in the relationship between the judiciary and the political branches. The starting point of the crisis can be traced to a leadership challenge against the then President of the United Malays National Organisation (UMNO), Mahathir Mohamad, who was also the Prime Minister of Malaysia, in $1987 .{ }^{45} \mathrm{UMNO}$ is the dominant political party of the Barisan Nasional (National Front) political coalition. This leadership challenge led to litigation, and the High Court ruled UMNO to be an unlawful society due to certain internal irregularities. ${ }^{46}$ Another controversial case concerned a legislative amendment that sought to grant the Attorney-General power to withdraw a criminal case after the commencement of proceedings and move it to another court. ${ }^{47}$ This, and several other cases decided against the government, are widely said to have motivated the Prime Minister to amend the constitution to curtail the powers of the judiciary by removing a vesting clause..$^{48}$ The original text of Article I 2I(I) of the Federal Constitution vested 'judicial power of the Federation ... in a Supreme Court and such inferior courts as may be provided by federal law.' ${ }^{39}$ The amendment substituted this with a provision that states instead:

There shall be two High Courts of co-ordinate jurisdiction and status ... and such inferior courts as may be provided by federal law; and the High Courts and inferior courts shall have such jurisdiction and powers as may be conferred by or under federal law.

At the same time, Article I2I(IA) was added to the Federal Constitution to state that the High Courts 'shall have no jurisdiction in respect of any matter within the

4I. This deference is best understood as respect, rather than submission, or as due deference. This distinction between deference as submission and deference as respect is drawn from Dyzenhaus' work. See David Dyzenhaus, 'The Politics of Deference: Judicial Review and Democracy', in Michael Taggard (ed), The Province of Administrative Law (Hart Publishing I997) 279, 286. See also Alison L Young, 'In Defence of Due Deference' (2009) 72 The Modern Law Review 554, 559-564.

42. See Karam Singh v Menteri Hal Ehwal Dalam Negeri, Malaysia [1969] 2 MLJ I 29 (Federal Court), where the Court held that the question of whether it is necessary for a person to be detained without trial for national security reasons is 'a matter for the person or subjective satisfaction of the executive authority'.

43. Lob Kooi Choon (n 34).

44. [I980] I MLJ 70 (Federal Court).

45. George Seah, 'Crisis in the Judiciary: The Hidden Story' (Aliran Monthly, I May 2004) <https:// aliran.com/archives/monthly/2004a/4m.html> accessed 29 Apr 2020.

46. Mohd Noor Bin Othman \& Ors v Mohd Yusof Jaafar \& Ors [1988] 2 MLJ I29 (High Court).

47. PP $v$ Dato’ Yap Peng [1987] I CLJ 550 (Supreme Court).

48. Zairil Khir Johari, 'The Story of Malaysia through its Constitution' (New Mandala, 22 Aug 20I7) $<$ www.newmandala.org/story-malaysia-constitution/> accessed 29 Apr 2020.

49. Federal Constitution, art I2I(I) (before Io Jun I988). 
jurisdiction of the Syariah courts.' This new provision served to preclude alleged interference by the civil courts in overruling decisions by the Syariah courts. It was also during this time that the Lord President of the Supreme Court and several other judges were put through disciplinary proceedings after they protested the executive interference in judicial powers, and subsequently dismissed. ${ }^{50}$ The result was a weakened judiciary that was unable to defend itself against the political branches, even if the occasion arose. In the aftermath of this crisis, the basic structure doctrine did not feature in judicial reasoning. Instead, during this time, the courts appeared to acquiesce to a subordinate position within the Malaysian constitutional order, affirming that judicial power of the general courts was effectively limited. The case of Public Prosecutor $v$ Kok Wah $K_{u a n^{5}}{ }^{\mathrm{I}}$ highlights this judicial retreat, while several cases show increasing deference by the civil courts to the Syariah courts.

The third period coincides with the emergence of the judiciary from this period of crisis. Since 20I0, the judiciary appears to be rediscovering its judicial authority and one of the ways in which it has done so is by engaging with and embracing (though tentatively at first) the basic structure doctrine. Significantly, this came on the heels of a truth and reconciliation process in 2008 where an independent Panel of Eminent Persons cleared the dismissed Supreme Court judges of any wrongdoing and concluded that there was no cogent material available to frame a triable charge against the Lord President, Tun Salleh Abas. ${ }^{52}$ The Panel even opined that the Lord President was merely performing his constitutional duty to uphold and protect the doctrine of separation of powers and the rule of law. ${ }^{53}$ Although this was not an official panel convened by the Malaysian government, the panel's findings were weighty as it was backed by the Malaysian Bar Council, the International Bar Association, LawAsia, and Transparency International. ${ }^{54}$ Tellingly, the Malaysian government made reparations to the sacked judges in the same year. The Panel's conclusions were crucial in repairing the reputations of the respective judges, and in restoring the dignity of the judiciary. It is during this period that the courts have gradually embraced the basic structure doctrine. I examine these cases to show that the incremental adoption of the basic structure doctrine has been crucial in bolstering the courts' reinstatement of the view that judicial power is inherent and exclusive to the judiciary.

50. Tun Salleh Abas \& K Das, May Day for Justice: The Lord President's Version (Magnus Books I989); Andrew J Harding, 'The I988 Constitutional Crisis in Malaysia' (I990) 39 International \& Comparative Law Quarterly 57; Visu Sinnadurai, 'The I988 Judiciary Crisis and its Aftermath', in Andrew Harding \& HP Lee (eds), Constitutional Landmarks in Malaysia: The First 50 Years 1957-2007 (LexisNexis 2007) I73; HP Lee, 'The Malaysian Constitution after 50 Years Retrospective, Prospective and Comparative Perspectives' (2007) 9 Australian Journal of Asian Law 307.

5I. [2007] 6 CLJ 34I (Federal Court).

52. Panel of Eminent Persons, 'Report of the Panel of Eminent Persons to Review the I 988 Judicial Crisis in Malaysia' (The Malaysian Bar, 26 Jul 2008) <www.malaysianbar.org.my/index.php? option=com_docman\&task=doc_view\&gid=I7I 5 \&Itemid=332> accessed 20 Jul 20 I 8.

53. ibid para $\mathbf{I} 7 \cdot 3$.

54. ibid. 


\section{A. Resistance to the Basic Structure Doctrine and Deference to the Legislature}

The early rejection of the basic structure doctrine in Malaysia is consistent with a formalist approach grounded in a common law perspective of the relationship between the judiciary and the political branches of government. The Federal Court had in the 1976 case of Ab Thian $v$ Government of Malaysia ${ }^{55}$ affirmed that the doctrine of parliamentary supremacy does not apply to Malaysia, and that legislative bodies do not have absolute power to make any laws that they want. However, a strong note of deference to the legislature was sounded in the case of Loh Kooi Choon v Government of Malaysia, ${ }^{56}$ which addressed the applicability of the basic structure doctrine in Malaysia. This case involved a challenge to a constitutional amendment to a part of Article 5 of the Federal Constitution, which guarantees the liberty of the person. The appellant had been arrested without a warrant and detained for more than twenty-four hours without being produced to a Magistrate, which was required under Article 5(4). He sought damages, but before his appeal was heard, an amendment was made to the relevant article, retrospectively excluding arrests or detentions under the law relating to restricted residence.

The Federal Court rejected the challenge, holding that Parliament can alter any provisions of the Federal Constitution as long as the constitutional amendment procedure is complied with. Furthermore, it held that once a provision is amended, it becomes an integral part of the law and thereby part of the supreme law. It even held that although the amendment had retrospective effect, this was something within Parliament's competence to decide and the Court would apply the retrospective provision if enacted. According to Raja Azlan Shah FCJ, 'Parliament is endowed with plenary powers of legislation and ... it is within the ambit of its competence to legislate with prospective or retrospective effect' ${ }^{37}$ Addressing the attempt to introduce the basic structure doctrine, ${ }^{58}$ Raja Azlan Shah FCJ took an originalist position. He rejected the idea that there can be implied restrictions on amendment powers, holding that the drafters would have included it in the Federal Constitution if they had intended to make fundamental rights inviolable by constitutional amendment. As he put it, the drafters must have assumed that by imposing higher requirements for constitutional amendments, and thereby requiring the consent of a larger proportion of its members, Parliament would pass those amendments after 'mature consideration' and broader consensus. ${ }^{59}$

In his concurring opinion, Wan Suleiman FCJ further argued that the basic structure doctrine could not be adopted because the Federal Constitution does not contain

55. [I976] 2 MLJ I I2 (Federal Court). The Federal Court is the highest court in Malaysia and is empowered to issue binding interpretations of the Federal Constitution.

56. Loh Kooi Choon (n 34).

57. ibid I90.

58. As India is a fellow Commonwealth country that has inherited similar legal and constitutional traditions, Indian Supreme Court decisions have always had traction in Malaysia. This is especially since the fundamental liberties section in Malaysia's Federal Constitution draws from the Constitution of India. See Joseph M Fernando, The Making of the Malayan Constitution (MBRAS 2002) 2 I 2.

59. Loh Kooi Choon (n 34) I 89 . 
a preamble from which one could identify fundamental provisions that cannot be amended. ${ }^{60}$ This is in contrast with the Constitution of India, whose preamble and directive principles are important sources from which to derive the basic structures of the constitution. According to Wan Suleiman FCJ, if there were to be any restrictions on the power to amend fundamental rights, this would have been explicitly set out in the Federal Constitution itself. ${ }^{61}$

Clearly, the judgment in Loh Kooi Choon evinces strong deference, which it sees as due deference to Parliament. ${ }^{62}$ In his judgment, Raja Azlan Shah FCJ sketched out a limited role for the court vis-à-vis the legislature, which is premised upon a clear distinction between law and politics. ${ }^{63}$ According to the learned judge, the doctrine of implied restrictions on constitutional amendment powers is a 'fallacy' as it 'concedes to the court a more potent power of constitutional amendment through judicial legislation than the organ formally and clearly chosen by the Constitution for the exercise of the amending power. ${ }^{64}$ While he accepted that it is the 'province of the courts to expound the law', he nonetheless stated that those who wish to challenge the 'wisdom or expediency' of a law and claim 'vexatious interference of fundamental rights, normally must address themselves to the legislature and not the courts'. ${ }^{65}$ Indeed, he emphasized: 'they have their remedy at the ballot box'. ${ }^{66}$ At another juncture, Raja Azlan Shah FCJ also stated that the question of whether a law is 'harsh and unjust' is not for judicial determination but is 'a question of policy to be debated and decided by Parliament'. ${ }^{67}$

However, even though the Federal Court declined to adopt the basic structure doctrine, it is interesting that the court did not consider it an exercise in imponderables to identify core features of the Federal Constitution. In fact, it acknowledged that the Federal Constitution contains certain basic ideas. Justice Raja Azlan Shah observed the following:

The Constitution is not a mere collection of pious platitudes. It is the supreme law of the land embodying three basic concepts: One of them is that the individual has certain fundamental rights upon which not even the power of the State may encroach. The second is the distribution of sovereign power between the States and the Federation, that the I 3 States shall exercise sovereign power in local matters and the nation in matters affecting the country at large. The third is that no single man or body shall exercise complete sovereign power, but that it shall be distributed among the Executive, Legislative and Judicial branches of government, compendiously expressed in modern terms that we are a government of laws, not of men. ${ }^{68}$

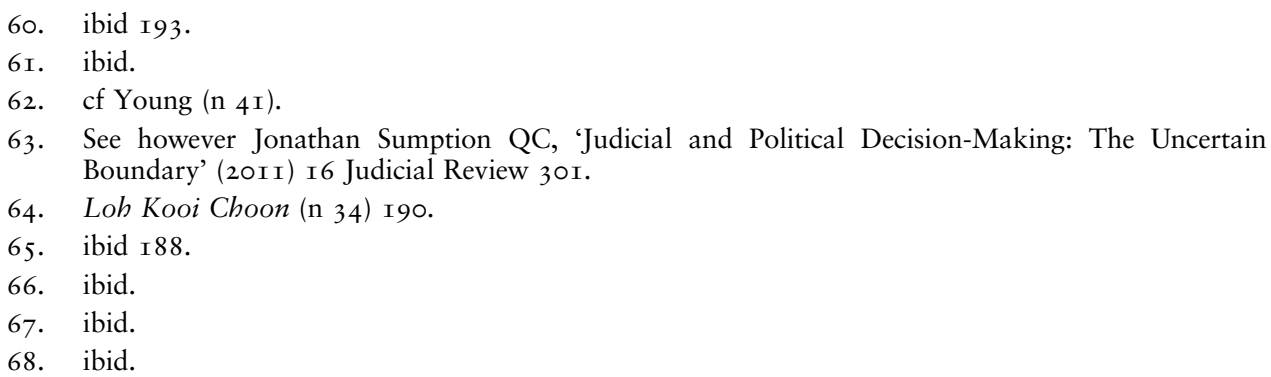


Reading this paragraph, one might suggest that the learned judge is identifying the basic structure of the Malaysian constitution as encompassing: (I) the protection of fundamental rights for individuals; $(2)$ the federal character of the constitution; and (3) the separation of powers. It is interesting to note that these coincide with some of the features identified as basic by the Indian Supreme Court in Kesavananda. For Chief Justice Sikri, for instance, the basic structure of the Indian Constitution comprises (I) the supremacy of the constitution; (2) the republic and democratic forms of government; (3) the secular character of the constitution; (4) separation of powers between the legislature, the executive, and the judiciary; and (5) the federal character of the Constitution of India. Furthermore, according to Chief Justice Sikri, dignity and freedom of the individual are the basic foundation to all these features. ${ }^{69}$ As can be seen, there is considerable overlap between Malaysia's putative list of basic features and that of the Indian constitution.

This resistance to the basic structure doctrine was also evident in the subsequent case of Phang Chin Hock $v$ Public Prosecutor. In this case, the Federal Court elaborated on its reasoning for not adopting the basic structure doctrine, largely by reference to what it appeared to consider the lack of an exercise of constituent power or a constitutional moment. ${ }^{70}$ In this case, the appellant had been convicted of the offence of unlawful possession of six rounds of ammunition contrary to the Internal Security Act 1960 (ISA) ${ }^{7 \mathrm{I}}$ and was sentenced to death. He challenged the constitutionality of the ISA as well as the amendments to the Federal Constitution that paved the way for the ISA to become law. The causal link was arguably tenuous. The appellant argued that amendments in 1978 increased the number of government appointed Senators so drastically that it allowed Parliament to convert the ISA to a permanent legislation and to expand its scope to cover a wider range of activities. In addition, there was a challenge to the I963 amendment to Article I50 of the Federal Constitution, which greatly enlarged the power of Parliament to make laws during an emergency. Prior to the amendment, Parliament could legislate on state subjects (except Muslim law and Malay custom), extend the duration of Parliament or a State Legislative Assembly, and suspend any election during an emergency. After the amendment, however, Parliament's legislative powers are without any limitations. It was thus argued that the amendments were so wide as to have destroyed the basic structure of the Federal Constitution or, alternatively, that they gave Parliament unlimited powers to destroy the constitution's basic structure during an emergency. ${ }^{72}$

The Federal Court rejected this argument, holding that Parliament may amend the Federal Constitution in any way it thinks fit, as long as it complies with the manner and form prescribed. In rejecting the applicability of the basic structure doctrine, the Court distinguished the Federal Constitution from the Constitution of India by highlighting that the latter was drafted by a 'sovereign Constituent Assembly', which

69. Kesavananda (n 6) 317.

70. Phang Chin Hock (n 44).

7I. Act No 82 of 1960 .

72. Phang Chin Hock (n 44) 72. 
deliberated over a period of time after independence on the constitution. ${ }^{73}$ As the Court put it, 'the Constitution [of India] was made by a Constituent Assembly not by ordinary mortals', and this has perhaps influenced the Indian courts to take the position that there are implied limitations on the amending power in order to protect fundamental liberties and the basic structure of the constitution. ${ }^{74}$ In addition, the Federal Court also observed, as it did in Loh Kooi Choon, that the Federal Constitution does not have a preamble or directive principles, unlike the Constitution of India. Hence,

it is understandable that Indian jurists should infer from the Preamble and Directive Principles ideas and philosophies animating the Indian Constitution and controlling its interpretation so much so that there are limits on the power of the Indian Parliament to amend their Constitution. ${ }^{75}$

In contrast, the Court said that the Federal Constitution is the fruit of joint Anglo-Malayan efforts' and 'there was no occasion for Malayans to get together to draw up a Constitution'. ${ }^{76}$ This means, according to the Court, that one could not conceptualize the Federal Constitution as an act of constituent power by the Malayan or Malaysian people. In other words, the Federal Constitution could not be especially protected from unconstitutional constitutional amendments because it was not an act of 'We, the People'.

Like in Loh Kooi Choon, the Court in Phang Chin Hock envisaged a limited role for the judiciary within the constitutional framework. The Court went even further in stating that ' $\mathrm{t}] \mathrm{h}$ he fear of abuse of Parliament's power to amend the Constitution in any way they think fit cannot be an argument against the existence of such power'. ${ }^{77}$ The Court's opinion that security cases should be treated differently also suggests that it sees the judicial function as being even more limited where national security issues are concerned. What is interesting, however, is that despite identifying what appear to be 'defects' in the genesis of the Federal Constitution, the Federal Court curiously hedged its position by stating that it was in any event unnecessary in this particular case to decide whether or not Parliament's power of constitutional amendment extends to destroying the basic structure of the Federal Constitution. ${ }^{78}$ It further concluded that ' $[\mathrm{w}]$ hatever may be the features of the basic structure of the Constitution, none of the constitutional amendments complained of and none of the impugned provisions of the Act have destroyed the basic structure of the Constitution'. ${ }^{79}$ This is highly curious, as an assessment that a particular constitutional amendment has not destroyed the basic structure of the constitution surely requires one to have an a priori conception of what the basic structure is!

73. ibid 73 .

74. ibid.

75. ibid.

76. ibid.

77. ibid 74 .

78. ibid 75 .

79. ibid. 
The Federal Court's qualified resistance to the basic structure doctrine in Loh Kooi Choon and Phang Chin Hock envisages a limited role for the judiciary against what it considers to be a 'political thicket'. ${ }^{80}$ This has to be understood in the context of the Malaysian judiciary's shared traditions and outlook with England, where the dominant constitutional doctrine is one of parliamentary sovereignty. This may also explain the prevalence during this time of a 'common law mindset', which tends to grant a great deal of deference to Parliament as supposedly the most democratic branch of government. ${ }^{8 \mathrm{I}}$ Nonetheless, it is important to note that on both occasions, the Court arguably left the door open to the possibility of future adoption. The Federal Court in Loh Kooi Choon identified what it considered to be 'basic concepts' of the Federal Constitution, whereas the Court in Phang Chin Hock suggested that the amendments had not destroyed the 'basic structure' of the constitution.

\section{B. Judicial Retreat and Indifference to the Basic Structure Doctrine}

As HP Lee observes, before the constitutional crisis in 1988, the Malaysian judiciary had enjoyed high prestige among judiciaries in many Third World countries since its independence in $1957 .{ }^{82}$ The constitutional crisis and the I 988 amendments seriously undermined judicial independence in Malaysia. It resulted in a significant shift in the relationship between the judiciary and the political branches whereby judicial power was in critical retreat. This is reflected in the lack of serious engagement with the basic structure doctrine until 20IO. Instead, the courts endorsed an interpretation of Article I 2I(I) that effectively subordinated judicial power to federal legislative control. This was the extraordinary position accepted by the Federal Court in the 2007 case of Public Prosecutor $v$ Kok Wah Kuan. ${ }^{83}$

The issue in this case was the constitutionality of a provision in the Child Act $200 I,{ }^{84}$ which stated that a person convicted of a capital offence could not be sentenced to death if he committed the offence when he was a child. Instead, the Court shall order that the convicted child be detained at the pleasure of the constitutional monarch or ruler. There was no disagreement within the Federal Court as to the outcome of the case. All the judges in Kok Wah Kuan agreed that this provision was constitutional as it did not impinge upon judicial power. What they disagreed on - the crux of Malanjum CJSS's dissent - was the interpretation and impact of the amended Article I2I(I). Taking a textualist interpretation of the new provision, the majority in

\footnotetext{
8o. Loh Kooi Choon (n 34), I 88 .

8I. See Speech by Justice Michael Kirby, Commissioner of the International Commission of Jurists (LawAsia, I988) <https:/www.michaelkirby.com.au/images/stories/speeches/I980s/volı9/752Lawasia_-_Malaysia_-_The_Judiciary_and_the_Rule_of_Law.pdf $>$ (accessed 30 Apr 2020), where he observed the historical link and the English tradition among Malaysian judges and lawyers, many of whom were trained in England. This common law thinking has also influenced judicial approaches in Singapore: see eg Jaclyn Neo \& Yvonne CL Lee, 'Constitutional Supremacy: Still a Little Dicey?' in Thio Li-ann \& Kevin YL Tan (eds), Evolution of a Revolution: Forty Years of the Singapore Constitution (Routledge 2008) I 53.

82. Lee (n 40).

83. See n 49 above.

84. Act 6 II of $200 I$.
} 
the Federal Court held that Article I2 I(I) of the Federal Constitution merely declares that the High Courts 'shall have such jurisdiction and powers as may be conferred by or under federal law', and this means that '[i]f we want to know the jurisdiction and powers of the two High Courts we will have to look at the federal law. ${ }^{85}$ The Court read the amendment as having substantive effect in removing the vesting of judicial power and thereby subordinating judicial power to legislative determination. The majority judgment stated that:

After the amendment, there is no longer a specific provision declaring that the judicial power of the Federation shall be vested in the two High Courts. What it means is that there is no longer a declaration that 'judicial power of the Federation' as the term was understood prior to the amendment vests in the two High Courts. If we want to know the jurisdiction and powers of the two High Courts we will have to look at the federal law. If we want to call those powers 'judicial powers', we are perfectly entitled to. But, to what extent such 'judicial powers' are vested in the two High Courts depend on what federal law provides, not on the interpretation the term 'judicial power' as prior to the amendment. That is the difference and that is the effect of the amendment. Thus, to say that the amendment has no effect does not make sense. There must be. The only question is to what extent? ${ }^{86}$

The majority eschewed what it called 'political theory'. ${ }^{87}$ In contrast, in his dissent, Malanjum CJSS articulated a theory of constitutionalism embracing limited government and constitutional democracy. The learned judge argued that judicial power is an important feature in a democratic system of government and that courts form the third branch of government with the specific duty 'to ensure that there is a "check and balance" in the system including the crucial duty to dispense justice according to law for those who come before them'. ${ }^{88}$ Furthermore, he invoked the doctrine of separation of powers and judicial independence as 'basic features' of the Federal Constitution. As he put it, 'I do not think that as a result of the amendment our courts have now become servile agents of a federal Act of Parliament and that the courts are now only to perform mechanically any command or bidding of a federal law'. ${ }^{89}$ Indeed, Malanjum CJSS clearly rejected parliamentary supremacy as Malaysia's constitutional doctrine when he stated that the courts are a 'separate and independent pillar of the Federal Constitution and not mere agents of the federal Legislature'. ${ }^{\circ}$ The learned judge argued that there are unwritten norms that underlie the Federal Constitution, which should be given effect. Unfortunately, however, the majority took the view that these norms may have influenced the framers of the constitution, but are not part of the constitution unless they have been specifically incorporated into the text. ${ }^{9 \mathrm{I}}$

85. Kok Wab Kuan (n 5I) para II.

86. ibid.

87. ibid para 18 .

88. ibid para 37 .

89. ibid para 38 .

90. ibid para 39.

9I. ibid. 
One impact of the I 988 amendments is that it intertwined judicial power and judicial independence with the relationship between the general courts and the Syariah courts. By seeking to delineate the jurisdiction of the Syariah courts from that of the general courts, the I988 amendments have made religious freedom part of the contestation for judicial power. The general courts are meant to uphold the constitution, which guarantees among others the right to freedom of religion under Article I I (I). However, there have been claims that Muslims are subject to the exclusive jurisdiction of the Syariah courts and therefore cannot claim the right to religious freedom to convert out of Islam without the approval of the Syariah courts. Thus, one outcome of the 1988 amendment is that the individual right to religious freedom has now been constitutionally pitted against an autonomy claim of a religious group to preserve its own system of courts. While the courts initially resisted any erosion of their judicial power in favour of the Syariah courts, there was eventually a shift in judicial opinion, which occurred in the context of increasing Islamization of politics and society in Malaysia. ${ }^{92}$ This shift in judicial opinion came some ten years later in 1999 case of Soon Singh all Bikar Singh $v$ Pertubuhan Kebajikan Islam Malaysia (Perkim) Kedah, where the Supreme Court departed from earlier jurisprudence and held that the civil courts had no jurisdiction over the question of a Muslim's personal status, even where the statute does not explicitly provide for conversion out of Islam. ${ }^{93}$ Instead, the court surprisingly held that jurisdiction could be conferred by implication, meaning that even if the statute does not provide for jurisdiction over a particular matter, it could be implied. This goes against the idea that Syariah courts are statutory bodies with limited jurisdiction, and furthermore only created by state (as opposed to federal) legislatures. ${ }^{94}$ In contrast, general civil courts are constitutional bodies with inherent jurisdiction.

The Soon Singh approach in deferring jurisdiction and judicial power to the Syariah court was most famously adopted in the internationally-publicized case of Lina Joy $v$ Majlis Agama Islam Wilayah Persekutuan, ${ }^{95}$ where the majority in the Federal Court held that the National Registration Department acted reasonably when it required the appellant to obtain a certificate of conversion from the Syariah Court before it would remove the word 'Islam' as the appellant's religion in her identity card. ${ }^{96}$ The Court held that renunciation is a matter that requires serious consideration and interpretation of Syariah law, and therefore falls within the

92. For a review of these cases, see Thio Li-ann, 'Jurisdictional Imbroglio: Civil and Religious Courts, Turf Wars and Article I2I(IA) of the Federal Constitution', in Andrew Harding \& HP Lee (eds), Constitutional Landmarks in Malaysia: The First Fifty Years 1957-2007 I97 (2007); see also Dian AH Shah, Constitutions, Religion and Politics in Asia: Indonesia, Malaysia and Sri Lanka (Cambridge University Press, 2017).

93. [I999] I MLJ 489, 496 (Supreme Court).

94. List II of the Ninth Schedule referred to in the Federal Constitution, art 74 authorizes state legislatures to enact religious (Syariah) laws on 'Islamic law and personal and family law of persons professing the religion of Islam', as well as offences against the precepts of Islam.

95. [2007] 4 MLJ 585 (Federal Court). The majority judgment is written in Malay; all references to the majority judgment in this article are based on my reading and are not direct quotes.

96. ibid para ıo. 
exclusive jurisdiction of the Syariah Court. ${ }^{97}$ Notably, at the moment, obtaining the certification from the Syariah Court is not a mere administrative procedure. Statutes governing the administration of Syariah laws in some constituent states in Malaysia often empower Syariah courts to impose conditions before certifying conversions, which could include detentions and/or repentance and rehabilitation classes. ${ }^{98}$ It was therefore curious for the Federal Court in Lina Joy to claim that there was no violation of the appellant's right to freedom of religion under Article II(I) on the basis that all that was required of her was to follow the requirements under Islam to renounce that religion and embrace Christianity. ${ }^{99}$ Thus, while the Federal Court did not conclusively state that Article II(I) does not include the right to choose one's religion, the effect, bearing in mind the difficulty and almost impossibility of obtaining a certificate of conversion from the Syariah Court, is exactly that. Interestingly, there was no discussion of the basic structure doctrine in these cases involving religious freedom of Muslims.

\section{From Ambivalence to Adoption: A New Era for Judicial Power and the Basic Structure Doctrine?}

Despite the early rejection and subsequent indifference, in Shad Faruqi's stark words, the basic structure doctrine 'refuses to die'. ${ }^{\text {I00 }}$ Since 2010, an increasing number of cases have been litigated and decided wherein judges increasingly embraced the doctrine as substantively limiting Parliament's amendment powers. ${ }^{\text {IOI }}$ The case of Sivarasa Rasiah $v$ Badan Peguam Malaysia, ${ }^{\mathrm{IO} 2}$ in particular, rejected the position in Loh Kooi Choon as having incorrectly adopted the doctrine of parliamentary sovereignty. The case concerned a constitutional challenge to a provision in the Legal Profession Act 1976 (LPA) ${ }^{\mathrm{IO}} 3$ which disqualifies, among others, a member of Parliament from serving on the Bar Council or a State Bar Committee. The appellant, an advocate and solicitor and a member of Parliament, wished to serve as an elected member of the Bar Council, the governing body of the Malaysian Bar, and challenged the restriction on the grounds that it violated his constitutional rights of equality, freedom of association, and personal liberty.

The Federal Court dismissed the challenge. In an important clarifying part, the Court identified two principles as encompassing the correct interpretive approach

97. ibid para IO.I.

98. See chapter on 'Malaysia' in Human Rights Resource Centre, 'Keeping the Faith: A Study of Freedom of Thought, Conscience, and Religion in ASEAN' (Human Rights Resource Centre 2015) <http:// hrrca.org/wp-content/uploads/20I5/I I/Book-of-Keeping-the-Faith_web.pdf> accessed 29 Apr 2020.

99. Lina Joy (n 95) para I4.

Ioo. Shad Saleem Faruqi, Document of Destiny: The Constitution of the Federation of Malaysia (Star Publications 2008) 564 .

IOI. Besides the cases discussed here, see also eg Muhammad Hilman bin Idham \& Ors $v$ Kerajaan Malaysia \& Ors [20II] 6 MLJ 507 (Court of Appeal); Kerajaan Malaysia v Shimizu Corp \& Ors [20I8] MLJU I69 (High Court).

I02. [20IO] 2 MLJ 333 (Federal Court).

I03. Act I 66 of 1976 . 
in protecting constitutional rights. First, fundamental liberties guaranteed under Part II of the Federal Constitution must be 'generously interpreted' and 'a prismatic approach' must be adopted. ${ }^{\text {I0 }}$ Secondly, provisos or restrictions that limit or derogate from a guaranteed right must be read restrictively. ${ }^{105}$ Even with this rights-protective approach, however, on the facts the Court dismissed the challenge. It held that the Malaysian Bar was not an association and that the right to freedom of association could not apply to it. ${ }^{106}$ Furthermore, even if the Bar could be subject to the right to freedom of association, the disqualifications were reasonable restrictions justified on the grounds of public morality. In this regard, the Court extended 'public morality' to include ensuring matters of discipline of the legal profession and its regulation, particularly in ensuring the absence of political influence and securing an independent Bar Council. ${ }^{\text {I07 }}$

Similarly, the Court held that there was no violation of the guarantee of equal protection because differentiating advocates and solicitors who were also members of Parliament and those who were not was a reasonable classification. ${ }^{\text {Io } 8}$ This ensures that the governance of the body would not be in the hands of those with political leanings. In addition, the Court held that the legislative restriction was proportionate to the object it sought to achieve, and did not violate any constitutional rights. ${ }^{\text {I09 }}$ At the core of the Court's judgment is its view that it is 'fair and just that the governance of a professional body be kept in the hands of professionals who have no other visible political interests that may create the perception that the Bar Council has political leanings.' ${ }^{\text {II }}$ A critical observation of the Court is that the impugned law did not restrict the appellant from being a member of the Malaysian Bar, but only from serving as a member of a distinctly separate body, the Bar Council. ${ }^{\text {II }}$

As may be evident, the Court's engagement with constitutional rights would have been sufficient to dispose of the matter. The basic structure doctrine was not relevant here as the challenge did not involve a constitutional amendment, but merely ordinary legislation. Nonetheless, as the basic structure doctrine was raised in argument, this gave the Court an opportunity to address what it considered to be an error in Loh Kooi Choon. According to the Federal Court, the earlier view that it is not within the scope of judicial determination whether an impugned Act is 'harsh and unjust' was in error as it was based on views expressed in an English case, within the context of a jurisdiction where Parliament is supreme. ${ }^{\text {II } 2}$ Thus, the Federal Court stated that:

\footnotetext{
104. Sivarasa (n 102) para 3.

I05. ibid para 5 .

I06. ibid para II.

I07. ibid para I2.

I08. ibid para 26.

I09. ibid para 33 .

I Io. ibid para 26.

III. ibid para I 5 .

II2. ibid para 8 .
} 
it is clear from the way in which the Federal Constitution is constructed there are certain features that constitute its basic fabric. Unless sanctioned by the Constitution itself, any statute (including one amending the Constitution) that offends the basic structure may be struck down as unconstitutional. ${ }^{\mathrm{II} 3}$

While the Court left open the question of what would constitute the Federal Constitution's basic structure, it was clear from the judgment that the rights guaranteed under Part II of the Federal Constitution could be part of this structure. ${ }^{\text {II } 4}$ Thus, Sivarasa clearly rejected the position in Lob Kooi Choon that Parliament has the power to amend the Federal Constitution as long as it complies with the prescribed procedure, embracing instead the idea that there are implied limits to Parliament's amendment powers. However, this part of its judgment is purely obiter dicta. The Federal Court in Sivarasa was not in fact dealing with the constitutionality of a constitutional amendment. The impugned provision was only statutory.

The basic structure doctrine was periodically considered by the High Court and the Court of Appeal in several cases after Sivarasa, with varying degrees of acceptance, though in none of the cases did the Malaysian courts actually strike down a constitutional amendment. The Federal Court's next important engagement with the basic structure doctrine came in the 2017 case of Semenyih Jaya Sdn Bhd v Pentadbir Tanah Daerah Hulu Langat. ${ }^{15}$ While the case raised issues concerning property rights, it was more concerned with the scope of judicial power. It was the first case where the Court had to deal squarely with the question of the constitutionality of a major constitutional amendment. The appellants had challenged the constitutional vires of the Land Acquisition Act $1960^{116}$, which had been amended in 1997 to empower two lay assessors sitting with the judge in the High Court to make final determinations on the amount of reasonable compensation for the acquisition of land under the Act. The Act also sought to preclude appeals against the High Court decision on the amount of compensation. The appellant owned a piece of land, part of which was compulsorily acquired for the purpose of constructing a public highway. Compensation was awarded but the appellant was not satisfied with the quantum of compensation because it did not take into account the loss of profits as well as costs and expenses incurred due to the termination of its planned commercial project. The key question in this case was whether the mode of assessment and the preclusion of appeals from the High Court transgressed into judicial power.

The Federal Court rejected the majority position in Kok Wab Kuan, which had basically subjected the jurisdiction and powers of the judiciary entirely to federal law, ie to the will of Parliament. It first, however, drew from an earlier judgment that stated that Article I2I is to be read in connection with its shoulder note, which contains the words 'judicial power'. ${ }^{\text {II }}$ The Court appeared to place great

II3. ibid (emphasis added).

II4. ibid para 8.

II 5. [20I7] 5 CLJ 526 (Federal Court).

I I6. Act 486 of 1960 .

I I7. Semenyih Jaya (n I I 5) para 62. See also Dato’ Seri Anwar Ibrahim v PP [2010] 7 CLJ 397 (Federal Court). 
reliance on this shoulder note when it stated that ' $[\mathrm{t}]$ he legal consequence is that art [icle] I2I(I) of the Federal Constitution states that judicial power or the power to adjudicate in civil and criminal matters brought to the court is vested only in the court'. ${ }^{\text {II }}$ It is questionable whether a mere shoulder note is sufficient to displace the clear intention of Parliament to change the terms of the constitutional provision. Far more convincing is the employment of foundational constitutional principles articulated in Malanjum CJSS's dissenting judgment in Kok Wab Kuan, which the Federal Court in Semenyih endorsed.

Where a constitutional provision could be interpreted in a way that is consistent with foundational constitutional principles, presumably courts have the option of adopting such an interpretation. This is reminiscent of the approach taken by common law judges in Australia and the United Kingdom where a 'principle of legality' ${ }^{\text {' } 9}$ or a 'clear statement rule' ${ }^{\mathrm{I} 20}$ applies. However, this may entail ignoring the clear intent of Parliament and interpreting the provision as having no such effect. In the alternative to such an interpretive approach, courts may then invoke the basic structure doctrine to invoke implied meta-constitutional norms to strike down the provision. The Federal Court was not entirely clear as to which approach it was taking in Semenyih Jaya. On the one hand, the Court, as discussed earlier, held that Article I2I did not have the effect of removing the vesting of judicial power in the High Courts, suggesting that it was reading down the effect of the amendment. In adopting Malanjum CJSS' dissenting opinion, it appeared to also endorse the point that despite the amendment, the courts remain a co-equal, and not a subordinate, branch of government. The courts' jurisdictions and powers are not to be dictated by the federal Parliament, but inhere in the courts as an a priori matter. This suggests an interpretive approach whereby the courts will simply read down the amendment as having no effect.

On the other hand, the Federal Court in Semenyih Jaya also stated that it is clear to us that the I988 amendment had the effect of undermining the judicial power of the Judiciary' and that it impinges upon the doctrine of separation of powers and the independence of the judiciary. ${ }^{\mathrm{I} 2 \mathrm{I}}$ The Court further stated that the removal of judicial power from the inherent jurisdiction of the judiciary meant that the institution was 'effectively suborned to Parliament, with the implication that Parliament became sovereign'. ${ }^{\text {I22 }}$ It then followed up with a discussion alluding to the basic features doctrine, but never clearly stated that it was adopting the doctrine. ${ }^{\mathrm{I} 23}$ The Court then

I 8 . Semenyih Jaya, ibid para 67.

I I9. R $v$ Secretary of State for Home Department; ex parte Simms [2000] 2 AC I I 5, I 3 I. See also David Dyzenhaus, Murray Hunt \& Michael Taggart, 'The Principle of Legality in Administrative Law: Internationalisation as Constitutionalisation' (200I) I Oxford University Commonwealth Law Journal $5,6, \mathrm{I} 8$.

I20. See eg Potter v Minahan (I908) 7 CLR 277 (High Court, Australia) 304 (O'Connor J); Brendan Lim, 'The Normativity of the Principle of Legality' (20I3) 37 Melbourne University Law Review 372; Dan Meagher, 'The Common Law Principle of Legality in the Age of Rights' (20II) 35 Melbourne University Law Review 449, 477.

I2I. Semenyih Jaya (n II5) para 74 .

I22. ibid para 75 .

I23. ibid paras 79-8I. 
stated that Parliament does not have the power to amend the Federal Constitution to the effect of undermining the doctrine of separation of powers and the independence of the judiciary, which it identified as 'features' of the Federal Constitution. ${ }^{\text {I24 The }}$ closest the Court got to endorsing the basic structure doctrine is when it stated that judicial power, judicial independence, and the separation of powers are 'as critical as they are sacrosanct' in the Malaysian constitutional framework. ${ }^{\mathrm{I} 25}$

The Federal Court in Semenyih Jaya, the dissenting judgment in Kok Wab Kuan, and the earlier panel of the Federal Court in Sivarasa clearly subscribe to a constitutional theory of the Federal Constitution as being premised on limited government and the doctrine of constitutional supremacy. The Court in Semenyih Jaya took time to reiterate the need for effective checks and balances, as well as to ensure that the legislature acts within its constitutional limits. This view of constitutionalism coheres with the doctrine of constitutional supremacy, where the constitution serves to impose legal limits on all branches of government. However, this view still does not squarely address the core of the problem, which is whether there are extra- or meta-constitutional norms that can be implied into the constitution to substantively control Parliament's legislative powers. This is the crux of the issue to be addressed by the basic features or basic structure doctrine. Indeed, unlike in Sivarasa, the question of whether the I 988 amendment had any effect is a real one that goes to the heart of the case at hand. To hold as it did that the impugned law 'effectively usurps the power of the court in allowing persons other than the judge to decide on the reference before it', ${ }^{126}$ and is thereby unconstitutional, requires the Court to accept that judicial power is exclusively vested in the courts and that any interference with judicial power would be unconstitutional. The Court's somewhat ambivalent engagement with the basic structure doctrine in Semenyih Jaya meant that the applicability and articulation of the doctrine in Malaysia had remained 'underdeveloped'. ${ }^{27}$

It was only in the 2018 judgment of Indira Gandhi Mutho $v$ Pengarah Jabatan Agama Islam Perak \& Ors ${ }^{\mathrm{I} 28}$ that the Federal Court clearly and firmly embraced the basic structure doctrine. This was a long-awaited case arising from a custody dispute over three children, who had been unilaterally converted to Islam by their father. The father had obtained custody orders in his favour from the Syariab Court while the mother had obtained custody orders in her favour from the High Court. It took almost ten years for the case to wind its way through the court system. In January 20I 8, the Federal Court conclusively determined the matter and quashed the conversion certificates of the three minor children on the basis that the Federal Constitution requires the consent of both parents (not just one) for the conversion of minors. The relevant provision, Article I 2(4), states that 'the religion of a person under the age of eighteen years shall be decided by his parent or guardian.'

I24. ibid paras 88,90 .

I25. ibid para 90.

I26. ibid para 52 .

127. Wilson TV Tay, 'Basic Structure Revisited: The Case of Semenyih Jaya and the Defence of Fundamental Constitutional Principles in Malaysia' (2019) I4 Asian Journal of Comparative Law II3, II 5 .

I28. [20I8] I LNS 86 (Federal Court). 
This case represents the clearest affirmation by the Federal Court of the basic structure doctrine. The issue that implicated the basic structure doctrine concerns whether the civil courts retain jurisdiction to determine legal questions concerning the religious status of Muslim converts. The Court departed from earlier cases where courts had held that the question of a person's personal status as a Muslim fell within the exclusive jurisdiction of the Syariah Court. ${ }^{\mathrm{I} 29}$ Until the case of Indira Gandhi, the Federal Court had always avoided directly answering the constitutional question of whether Article I I which guaranteed the right to freedom of religion included the right for a Muslim to choose his or her religion.

The I 988 constitutional amendments to article $\mathrm{I} 2 \mathrm{I}(\mathrm{I})$ and the inclusion of the new article I2I(IA) clearly intertwine the issue of judicial power with questions of jurisdictional delineation between the general or civil courts and the Syariab court. Thus, any move towards more robust protection of religious freedom will presumably also be connected with a restoration of constitutional judicial power. ${ }^{130}$ This was evident in Indira Gandhi. In this case, the Federal Court held that Article I2I(IA) does not 'oust the jurisdiction of the civil courts as soon as a subject matter relates to the Islamic religion'. ${ }^{\text {I I }}$ The Court further held that the Syariab courts should be regarded as limited tribunals, whose jurisdiction must be expressly conferred by state legislation and cannot be expanded by implication. Invoking the idea of a basic structure, the Court asserted that:

The powers of judicial review and of constitutional or statutory interpretation are pivotal constituents of the civil courts' judicial power under Article I2I(I)... As part of the basic structure of the constitution, it cannot be abrogated from the civil courts or conferred upon the Syariah Courts, whether by constitutional amendment, Act of Parliament or state legislation. ${ }^{\mathrm{I} 2}$

This assertion of judicial power rests upon the basic structure doctrine, in a way that is clearer than the Federal Court had done in the earlier case of Semenyih Jaya. In its clearest endorsement of the basic structure doctrine so far, the Federal Court in Indira Gandhi declared that 'the power of judicial review is essential to the constitutional role of the courts, and inherent in the basic structure of the Constitution' ${ }^{3} 3$ and, even more importantly, that it 'cannot be abrogated or altered by Parliament by way of a constitutional amendment'. ${ }^{\text {I34 }}$ Thus, the Court went on to state two legal implications of this holding. First, it said that judicial power cannot be removed from the civil courts. This would mean that any ouster clauses would be ineffective for

I29. See eg Lina Joy (n 95).

I30. Jaclyn L Neo, 'Return of Judicial Power: Religious Freedom and the Tussle over Jurisdictional Boundaries in Malaysia (I-CONnect Column)' (I-CONnect, I 5 Mar 20I8) <http://www.iconnectblog.com/20I 8/o3/return-of-judicial-power-religious-freedom-and-the-tussle-over-jurisdictional-boundaries-in-malaysia-i-connect-column/> accessed 20 Feb 2020.

I3I. Indira Gandhi (n I25) para I04.

I32. ibid (emphasis added).

I33. ibid (emphasis added).

I34. ibid para 48 . 
being unconstitutional. ${ }^{\mathrm{I} 5}$ Secondly, judicial power cannot be conferred on another body whose members do not enjoy the same level of constitutional protection as civil court judges. ${ }^{136}$ While it did not do so in specific words, the Court's adoption of the basic structure doctrine meant that both the amendment to Article I2I(I) and Article I 2 I IA) are invalidated in effect. Indeed, the Court did state that the amendment to include Article I2I(IA) does not oust the jurisdiction of the court as Parliament does not have the power to make any such constitutional amendment to give such an effect. ${ }^{137}$ Such an amendment 'would be invalid, if not downright repugnant, to the notion of judicial power inherent in the basic structure of the constitution'. ${ }^{138}$

The judiciary's increasing receptiveness to the basic structure doctrine serves to support its reclamation of judicial power. This reassertion of judicial power serves to signal the judiciary's independence from the political branches and is one pathway for the judiciary to restore public confidence in the administration of justice. ${ }^{139}$ Nonetheless, as retired judge Datuk Mohd Hishamudin Yunus suggested in a 2015 interview, 'after some 27 years since that dark episode, the Judiciary has probably recovered, but still to a very limited extent.' ${ }^{\mathrm{I} 4 \mathrm{O}}$ This is because, he says, there is still negative public perception against the judiciary, particularly with doubts concerning their independence. ${ }^{\mathrm{I} \text { I }}$ The treatment of the basic structure doctrine in future cases is likely to continue to reflect this evolving relationship between the judiciary and the political branches. The politicization of race and religion in Malaysia would continue to form an important social context within which judicial power is to be understood vis-à-vis the Syariah courts. ${ }^{\text {I }}{ }^{2}$

\section{CONCLUDING REFLECTIONS}

As Scheppele observes, constitutionalism must be seen as a set of lived practices and one that takes on a fluid dialectical nature. Not only do the transnational flow of ideas

I35. ibid para $5 \mathrm{I}$.

I36. ibid para 53. This follows the position taken by the Privy Council in Hinds $v$ The Queen [I977] AC I95.

I37. ibid para 92.

I38. ibid.

I39. The use of judicial codes as a way to communicate judicial values of impartiality and independence is another strategy to restore public confidence in the judiciary. See Jaclyn L Neo \& Helena Whalen-Bridge, 'A Judicial Code of Ethics: Regulating Judges and Restoring Public Confidence in Malaysia', in Richard Devlin \& Adam Dodek (eds), Regulating Judges: Beyond Independence and Accountability (Edward Elgar 2016) 279.

I40. Shaila Koshy \& M Mageswari, 'Judicial Crisis was a nightmare, says retired judge' The Star Online (20 Sep 20I 5) <https://www.thestar.com.my/news/nation/20I 5/09/20/judicial-crisis-was-a-nightmaresays-retired-judge/> accessed 29 Apr 2020.

I4 I. ibid.

I42. Notably, shortly after Indira Gandhi, the Federal Court decided another case in which it affirmed that the jurisdiction to hear cases on conversion out of Islam lies with Syariab court, which is in line with the Lina Joy decision. As the written grounds of decision in this case have not been made publicly available, it is not possible to examine whether and how (if at all) the Federal Court reconciled this decision with its account of judicial power in Indira Gandhi. See eg Sharon Ling, 'Federal Court rules jurisdiction to hear apostasy cases lies with syariah court' The Star (27 Feb 20I 8) <https://www.thestar.com.my/news/nation/20I 8/02/27/federal-court-dismisses-conversionappeals-case-to-be-heard-in-civil-court/> accessed 29 Apr 2020. 
'modify the lived experience of specific local sites', these 'national, local, and distinctive ideas' also modify the supposedly general and universalist meanings of these transnational ideas. ${ }^{\text {I43 }}$ If Malaysia's overarching constitutional identity is one of a constitutionalist state with limited government based on a supreme constitution, from which one can distil the doctrine of constitutional supremacy, then the judiciary will play some role in ensuring that the political branches, including Parliament, do not overreach. In the context of a dominant party state (like Malaysia was until recently), this overreach may extend even to constitutional amendments that radically change the original constitutional consensus. Where one political party is able to control a supermajority of seats in Parliament for an extended period of time, procedural limits provide no bar to constitutional amendments. The constitution may be formally rigid but flexible in practice. Under such conditions, invoking meta norms in the form of the basic structure doctrine, or interpreting the scope of amendments narrowly by reference to these norms, may well be necessary to preserve judicial power and independence.

The 2018 general elections in Malaysia may have opened up greater policy space for the judiciary to reassert its independence. ${ }^{\mathrm{I} 44}$ The toppling of the Barisan Nasional coalition that was in power for 6I years has given Malaysia a window of opportunity to restore democratic constitutionalism and strengthen constitutional controls over political power. Although the previously dominant political party, which lost the general elections, managed to wrest back power mid-term in April 2020 as part of a new coalition, ${ }^{\mathrm{I}}{ }^{45}$ the realignment of political alliances may continue to create instability in the political system. This evolving political context could have an effect on the extent to which the judiciary will be able to fully adopt the basic structure doctrine to reassert judicial power. Going forward, how the judiciary decides constitutional cases that come before it, especially where judicial power is implicated, will have a long-term impact on its standing within the constitutional framework. In this regard, judicial treatment of the basic structure doctrine is not only about trying to identify and protect foundational constitutional norms (ie Malaysia's constitutional identity), but also to restore judicial confidence and judicial prestige. The legitimacy and appropriateness of such a move may well be subject to challenge, but that is a discussion for another day.

I43. Scheppele (n 27) 390, 393-394.

I44. Jaclyn L Neo, Dian AH Shah \& Andrew Harding, 'Introduction to I-CONnect Symposium: Malaysia Boleh! Constitutional Implications of the Malaysian Tsunami' (International Journal of Constitutional Law Blog, 2I Jun 20I8) <http://www.iconnectblog.com/20I8/o6/introduction-to-iconnect-symposium-malaysia-boleh-constitutional-implications-of-the-malaysian-tsunami/> accessed I3 Apr 2020.

I45. Dian AH Shah \& Andrew Harding, 'Constitutional Quantum Mechanics and a Change in Government in Malaysia' (International Journal of Constitutional Law Blog 8 Apr 2020) <http:// www.iconnectblog.com/2020/04/constitutional-quantum-mechanics-and-a-change-in-governmentin-malaysia/> accessed I3 Apr 2020. 